\title{
Traditional medicinal plants used by tribal communities in Tonk district, Rajasthan
}

\author{
Swati Sharma \& Dipjyoti Chakraborty* \\ Department of Bioscience and Biotechnology, Banasthali Vidyapith, Banasthali-304 022, India \\ *Email: cdipjyoti@banasthali.in
}

\section{ARTICLE HISTORY}

Received: 28 December 2020

Accepted: 23 February 2021

Published: 27 March 2021

\section{KEYWORDS}

Ethnobotany

Tribal community

Tonk district

Traditional knowledge

\begin{abstract}
Rajasthan is the third largest state of India. About $80 \%$ of the population live in the villages. The main tribes of Rajasthan are Bhil, Meena, Garasia, Saharia, Damor and Kathoudi. The study area comprises of Tonk district of Rajasthan, India which has seven divisions Deoli, Malpura, Todaraisingh, Uniara, Peeplu, Tonk and Newai. Survey method was followed covering five villages of each division. The data were collected through direct interviews with local people, priests, local physician and gardeners. A detailed questionnaire was designed and written in Hindi for the baseline study following standardised procedures. The tribal communities use plants and plant products in their day to day life, however there is a gap in knowledge in the younger generation. A total of 147 species belonging to 62 vascular plant families are reported. From these 145 species were reported to be used for medicinal applications, 135 species of which were used to treat more than one disease and remaining 8 species were used to treat only one disease. The most widely used plant part is leaves ( 95 species) and the, most common mode of application is oral (39.65\%). The traditional knowledge about the plants can be used to produce to new products for medicinal use, food and fodder.
\end{abstract}

\section{Introduction}

Ethnobotany is interrelationship between the plants and people. Rajasthan, the third largest state of India is famous for its cultural traditions and heritage. About $80 \%$ of the population lives in the villages in harmony with the nature. About $12.44 \%$ of the population belong to tribes such as the Bhil, Bhil-Mina, Damor, Dhanka, Garasia, Kathodi, Kokna, Kolidhor, Naikara, Patelia, Mina and Seharia and reside in remote areas devoid of basic infra-structure facilities (1). These tribal communities have accrued considerable knowledge of the nature and its preservation.

Tribal communities utilize plants as food, drugs, refreshments, narcotics, bug sprays, timbers, gums and colors (2). Study of interrelationship between plants and communities reveals considerable use of plants in daily life especially for health care and food. Traditional medication has played an important role in acquiring novel health care products from plants.
The present study was undertaken in the Tonk district of Rajasthan to rediscover traditional knowledge for sustainable utilization of natural resources. Bhil and Mina are the dominating tribal population in Tonk District (3). Locally available plants and plant products are extensively used for food, fodder and cure of the diseases of both people and their animals. The tribal communities exchange their knowledge within the groups and pass it on to the next generation. However, majority of the younger generation is largely unaware and unconcerned regarding the traditional use of plants and plant products (4).

\section{Materials and Methods}

The study area comprises of Tonk district of Rajasthan, India which has seven divisions Deoli, Malpura, Todaraisingh, Uniara, Peeplu, Tonk and Newai. The total area of this district is 7194 sq. $\mathrm{km}$ and located in the northwestern part of Rajasthan between 75.19 and 76.16 east longitudes and 25.41 and 26.24

(C) Sharma \& Chakraborty (2021). This is an open-access article distributed under the terms of the Creative Commons Attribution License, which permits unrestricted use, distribution and reproduction in any medium, provided the original author and source are credited (https://creativecommons.org/licenses/by/4.0/).

To cite this article: Sharma S, Chakraborty D. Traditional medicinal plants used by tribal communities in Tonk district, Rajasthan. Plant Science Today. 2021;8(2):225228. https://doi.org/10.14719/pst.2021.8.1.1077 
north latitudes. The average rain fall of this area is 62 $\mathrm{mm}$ (5). The main occupations of the people are agriculture and animal husbandry. During the survey five villages of each division were covered. The study was conducted during 2014-19.

Visits were conducted to villages for collection of information about the locally available plants. The data were collected through direct interviews with local people, priests, local physician and gardeners. Prior Information Consent was taken and the data was used only for research purposes. A detailed questionnaire comprising was designed for the baseline study following standardised procedures (6). The questionnaire was in Hindi dialect. The questionnaires were distributed among a varied population in these villages whose age ranged from 20 to 85 years to document the present state of knowledge regarding traditional uses of natural resources in daily life. The survey had equal number of male and female participants with higher participation of middle aged persons (30-40 years age). The questionnaire was based on socio-economic and demographic profile of the community, local plant products utilized for food, fodder, health hazards, family planning, social hygiene, childcare, festival etc. The local names, scientific name, family name, part used and medicinal value of the plants has noted and documented. The herbarium at Banasthali Vidyapith (BURI) and Rajasthan University Herbariun (RUBL) was used to identify the plants and voucher specimens are submitted to the Banasthali Vidyapith Herbarium. Plant names are consistent with those given in the web portalwww.plantsoftheworldonline.org

\section{Results}

Detailed field survey of the villages of Tonk district, Rajasthan was done to collect relevant and useful information, regarding the ingredients of home remedies in use. During the survey the rural areas of Tonk district were visited. People of different castes, localities, communities, ages and origin were interviewed and information regarding the plant products utilized. The economy of the area is mainly dependent on agriculture. Many of the villages do not have access to education, medical facility is poor and availability of food is very limited due to arid condition of the soil and constraints of water.

After initial hesitation and repeated visits, the information on the plants and their uses were more readily obtained. The survey although being gender neutral, has nearly equal number of male and female participants. Although the use of some common plants was known to all, housewives and elderly people have more knowledge of specific plants of medicinal importance.

A total of 147 species belonging to 62 vascular plant families are reported. From these 145 species were reported to be used for medicinal applications, 135 species of which were used to treat more than one disease and remaining 8 species were used to treat only one disease.
The largest number of medicinal plants in use belongs to the family Fabaceae $(8.84 \%)$. These plant species are listed in Supplementary Table 1 with their vernacular names, uses and mode of preparation. The number of plant species used in home/ traditional remedies and its percentage is represented in Table 1 . The survey reveals that these plants are used mostly for treating gastric disorder $(16.32 \%)$, respiratory disorder $(9.62 \%)$, skin diseases $(8.58 \%)$, cuts and wounds $(8.37 \%)$, eye, ear, nose problems (7.53\%), arthritis (6.90\%), headache (6.69\%), dental problems (5.86\%), fever (4.18\%), Dysuria, heart and blood disorder (2.93\%).

Table 1. Number of plant species used in home/ traditional remedies.

\begin{tabular}{clcc}
\hline Sl. No. Disease & $\begin{array}{c}\text { Total number of } \\
\text { plant species used }\end{array}$ & $\begin{array}{c}\text { \% of plant } \\
\text { species }\end{array}$ \\
\hline 1 & $\begin{array}{l}\text { Heart and blood } \\
\text { problems }\end{array}$ & 14 & 2.93 \\
\hline 2 & Dysuria & 14 & 2.93 \\
\hline 3 & Fever & 20 & 4.18 \\
\hline 4 & Dental problems & 28 & 5.86 \\
\hline 5 & Headache & 32 & 6.69 \\
\hline 6 & Arthritis & 33 & 6.90 \\
\hline 7 & Eye, ear, nose problem & 36 & 7.53 \\
\hline 8 & Cuts and wounds & 40 & 8.37 \\
\hline 9 & Skin diseases & 41 & 8.58 \\
\hline 10 & Respiratory & 46 & 9.62 \\
\hline 11 & Gastric disorder & 78 & 16.32 \\
\hline 12 & Others & 96 & 20.08 \\
\hline
\end{tabular}

The plant parts used in the traditional preparations is represented in Fig. 1 and the proportion of different methods used for preparation of medicinal formulations represented in Fig. 2. The most widely used plant part is leaf (95 species) and the, most common mode of application is oral (39.65\%).

Traditional methods of cure using medicinal plants are the most important means of health care for both people and their pets. Some species like Azadirachta indica, Acacia nilotica, Ricinus communis,

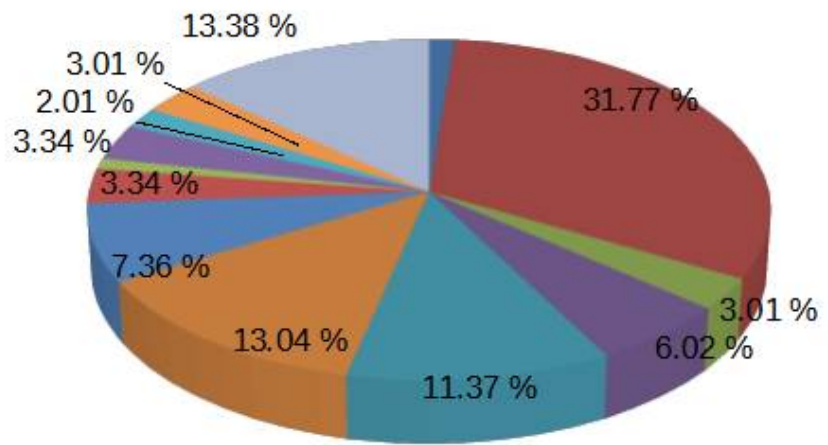

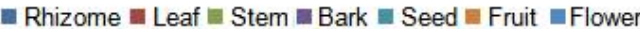

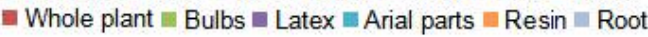

Fig. 1 Plant parts use (\%) in traditional medicinal preparations.

Pedalium murex, Aloe barbadadensis etc. are frequently used as medicine by the tribal communities.

Zizyphus nummularia is a much branched prickly shrub, commonly found in waste land 


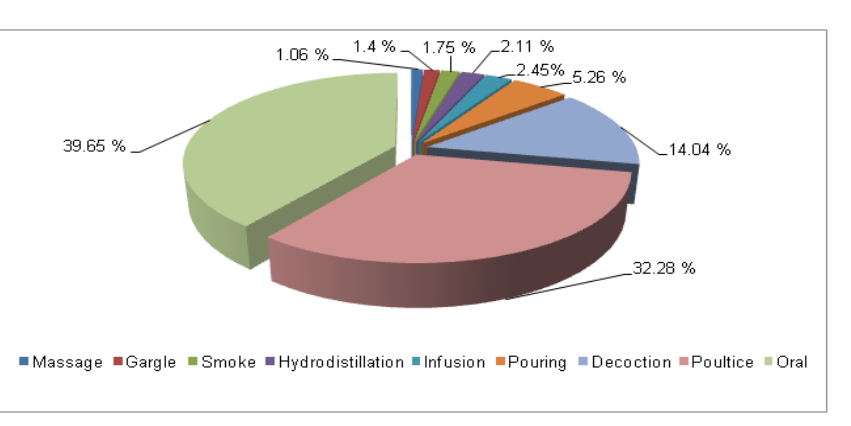

Fig. 2. Mode of preparations/ application of traditional remedies (\%).

especially in desert regions. Dry root powder of $Z$. nummularia is used to remove the weakness after delivery. The leaves are antipyretic and helpful in reducing obesity. The natural product is cooling, tonic, digestible, laxative aphrodisiac and removes biliousness, thirst, vomiting and burning sensations (7). The dried fruits are very useful in purifying blood and improving digestion; also give orally in the treatment of loss of appetite, chronic fatigue, diarrhoea, bronchitis, burns, anaemia, irritability, hysteria (8). The drug has been scientifically validated for certain pharmacological effects viz. antitumor (9), anthelmintic (10), antibacterial $(11,12)$ and antifertility effects (13).

Coriander is a famous spice which known for its taste and fragrance and is known to have antimicrobial activity $(14,15)$.

It is reported that that the tribal communities of Udaipur region, apply the paste of the leaves of the plant Kirganelia reticulata to cure epistaxis and decoction of roots with the leaves to cure tetanus (16).

Acyranthus aspera is very common plant, found in the waste land. In Baragh district of Orissa, paste of whole plant is beneficial for skin diseases (17). It is reported that plant is also used for quick labour, Pneumonia, loose motion, jaundice, scorpion bite, eczema, itches and typhoid (18).

Desmostachya bipinnata is a perennial herb, commonly found in open forests on rocky and sandyloam soil. Local people use the paste of leaves for healing the cuts and wounds. Roots of $D$. bipinnata are utilized within the Indian conventional framework of medication as cooling, sweet, astringent, diuretic and galactagouge additionally valuable in loose bowels, urinary calculi, dysuria, other illnesses of bladder and skin maladies (19).

Many plants are used in veterinary purposes including Tamarindus indica, Capparis decidua, Azadirachta indica, Sesbania bispinosa.

It was observed that some locally available species like Prosopis cineraria (20-22), Saccharum bengalense, Vetiveria zizanioides (23), Ailanthus excelsa (24) etc. have medicinal significance but there is a lack of awareness among the people.

Nine species have been recorded for non medicinal uses including fodder, fuel, edible, tanning of leather, natural dyes, rope, basket making, broom making, furniture making. Seeds of Balanites aegyptiaca is used to wash cloths. Achyranthus aspera is used for the worship, especially during the Goverdhan festival. Latex of Pheonix dactylifera is used for making Gur or jaggery, a sweetener. Origanum majorana is snake repellent plant due to its strong fragrance. Seed of Gossypium herbaceum is used as animal fodder and increase milk. Wood of Azadirachta indica, Acacia nilotica, Dalbergia sissoo and Prosopis cineraria are used to make furniture. Saccharum bengalense, Vetiveria zizanioides are used for making rope. Wood of Ailanthus excelsa is used for paper making.

Around $80 \%$ of the world populace depends on conventional medications for essential wellbeing and plant based medicine forms the base of numerous of the today's cutting edge pharmaceutical drugs utilized for different afflictions (25). However, due to the communication gap between the old and young generation, the traditional knowledge is being lost.

\section{Conclusion}

Plants and plant products are used extensively by tribal communities for their day to day use and the traditional knowledge can be utilised to produce new products for medicinal use, food and fodder. A survey was conducted in the Tonk district of Rajasthan, India and five villages in the seven divisions of the district. The responses noted to a detailed questionnaire on the use to plants in daily life. A total of 147 species belonging to 62 vascular plant families are reported. From these 145 species were reported to be used for medicinal applications, 135 species of which were used to treat more than one disease and remaining 8 species were used to treat only one disease. The most widely used plant part is leaf (95 species) and the, most common mode of application is oral (39.65\%).

\section{Acknowledgements}

SS acknowledges DST, Govt. of India for project funding (No. CO/S/TR/F05/2012, dated 16.10.2012). Plant Taxonomists in Banasthali Vidyapith and University of Rajasthan who have authenticated the plant specimens and the traditional healers who have shared their knowledge are acknowledged.

\section{Authors' contributions}

SS conducted the study, compiled the results. DC conceived of the study and participated in its design and coordination. All authors read and approved the final manuscript.

\section{Conflict of interests}

The authors declare that no conflict of interest exists in the course of conducting this research. Both the authors had final decision regarding the manuscript and the decision to submit the findings for publication. 


\section{Supplementary files}

Supplementary Table 1: List of medicinal plants used in traditional cure in Tonk district.

\section{References}

1. Sharma H, Kumar A. Ethnobotanical studies on medicinal plants of Rajasthan (India): A review. J Med Plant Res. 2011;5(7):1107-12.

2. Pareek A, Trivedi PC. Ethnobotanical studies on medicinal plants of Kaladera region of Jaipur district. Indian J Fund Appl Life Sci. 2011;1(1):59-63.

3. Rajasthan - Data Highlights: The Scheduled Tribes. Census of India 2001 [Internet]. Office of the Registrar General, India; 2018 [cited 2020 Dec 28]. Available from https://censusindia.gov.in/Tables_Published/SCST/dh_st_rajasth an.pdf

4. Praveen, Upadhyay B, Roy S, Kumar A. Traditional uses of medicinal plants among the rural communities of Churu district in the Thar Desert, India. J Ethnopharmacol. 2007; 113(3):387-99. https://doi.org/10.1016/j.jep.2007.06.010

5. Water Resources Department, Government of Rajasthan Mansoon Report - 2018 [Internet]. Rajasathan: Central Flood Cell; 2018 [cited 2020 Dec 28]. Available from: https://water.rajasthan.gov.in/content/dam/water/waterresources-department/Rainfall/MonsoonReport/Monsoon \%20report\%202018.pdf

6. Edwards S, Nebel S, Heinrich M. Questionnaire surveys: methodological and epistemological problems for field-based ethnopharmacologists. J Ethnopharmacol. 2005;100(1-2):30-36 https://doi.org/10.1016/j.jep.2005.05.026

7. Chopra RN, Nayar SC, Chopra IC. Glossary of Indian Medicinal Plants. Council of Industrial and Scientific Research, New Delhi; 1986.

8. Singh AK, Raghubanshi AS, Singh JS. Medical ethnobotany of the tribals of Sonaghati of Sonbhadra district, Uttar Pradesh, India. J Ethnopharmacol. 2002; 81(1):31-41. https://doi.org/10.1016/s0378-8741(02)00028-4

9. Singh SS. Phytoconstituents of Ziziphus nummularia (Burm. f.) Wight \& Arn. leaves extracts using GC-MS Spectroscopy. J Life Sci. 2019; 9(1):109-18. https://doi.org/10.37591/rrjols.v9i1.1331

10. Bachaya HA, Iqbal $Z$, Khan MN, Sindhu ZU, Jabbar A. Anthelmintic activity of Ziziphus nummularia (bark) and Acacia nilotica (fruit) against Trichostrongylid nematodes of sheep. J Ethnopharmacol. 2009; 123(2):325-29. https://doi.org/10.1016/j.jep.2009.02.043

11. De Boer HJ, Kool A, Broberg A, MzirayWR, Hedberg I, Levenfors JJ. Anti-fungal and anti-bacterial activity of some herbal remedies from Tanzania. J Ethnopharmacol. 2005;96:461-69.

12. Nair R, Chanda S. Activity of some medicinal plants against certain pathogenic bacterial strains. Indian J Pharmacol. 2006 38(2):142-44. https://doi.org/10.4103/0253-7613.24625

13. Shah GM, Khan MA, Ahmad M, Zafar M, Khan AA Observations on antifertility and abortifacient herbal drugs. Afr J Biotechnol. 2009;8(9):1959-64.

14. Silva F, Ferreira S, Queiroz JA, Domingues FC. Coriander (Coriandrum sativum L.) essential oil: its antibacterial activity and mode of action evaluated by flow cytometry. J Med Microbiol. 2011; 60(10):1479-86. https://doi.org/10.1099/jmm.0.034157-0

15. Sharma S, Chakraborty D. Antimicrobial and antioxidant activity of Coriandrum sativum L. Ann Phytomed. 2019; 8(1):135-39. https://doi.org/10.21276/ap.2019.8.1.17

16. Singh V, Pandey RP. Ethnobotany of Rajasthan. Scientific Publishers (India), Jodhpur. 1998.

17. Sen SK, Behera LM. Ethnomedicinal plants used against skin diseases in Bargarh district in Orissa. Ethnobot. 2003;15(1\&2):90-96.

18. Shekhawat D, Batra A. Ethnobotany of some household remedies used against animal and insect bite in Bundi district, Rajasthan. Ethnobot. 2006; 18:131-34.

19. Joshi SG. Medicinal plants. Oxford \& IBH publishing Co. Pvt Ltd, New Delhi, India. 2003; pp: 318.

20. Chopra RN, Nayar SL, Chopra IC. Glossary of Indian Medicinal Plants. Council of Industrial and Scientific Research, New Delhi. 1956; pp: 204.

21. Malik A, Kalidhar SB. Phytochemical investigation of Prosopis cineraria (L.) Druce leaves. Indian J Pharm Sci. 2007; 69:576-78. https://doi.org/10.4103/0250-474X.36950

22. Velmurugan V, Arunachalam G, Ravichandran V. Anthelmintic potential of Prosopis cineraria (Linn.) Druce stem barks. Asian J Plant Sci Res. 2011; 1(2):88-91.

23. Jha P, Jindal R, Chakraborty D. HPLC quantification of phenolic acids from Vetiveria zizanioides (Linn.) Nash and its antioxidant and antimicrobial activity. J Pharmaceutics. 2013;1-6. Article ID 270472. https://doi.org/10.1155/2013/270472

24. Shrimali M, Jain DC, Darokar MP, Sharma RP. Antibacterial activity of Ailanthus excelsa Roxb. Phytother Res. 2001; 15(2):165-66. https://doi.org/10.1002/ptr.706

25. Sandhya B, Thomas S, Isabel W, Shenbagarathai R. Ethnomedicinal plants used by the Valaiyan community of Piranmalai Hills, Tamil Nadu, India - A pilot study. Afr J Tradit Complement Altern Med. 2006; 3(1):101-14. https://doi.org/10.4314/ajtcam.v3i1.31145 